\title{
Kepemimpinan Berbasis Budaya Religius di MI Terpadu Al-Ishlah Gorontalo
}

\author{
Sintyawati Kaaba, Kadim Masaon, Arwildayanto \\ Universitas Negeri Gorontalo, Gorontalo \\ Email: sintyakaaba@gmail.com
}

\begin{abstract}
This study aims to describe: (1) preparation of religious culture-based school programs, (2) implementation of religious culture-based activities, (3) values applied in religious culture-based leadership, and (4) habituation of school community in implementing the religious culture. This study used a qualitative approach with a case study. Data were collected using observation, interview, and documentation. Data were analyzed by using an interactive model; data reduction, data presentation, and conclusions. Checking the validity of data extends the presence of researchers in the study sites, deep observation, triangulation of sources and researcher's methods/techniques and member check. The results show: (1) preparation of religious culture-based school programs such as the principal planning early in the semester to create a program of school activities involving school personnel, such as teachers and staffs, (2) implementation of religious culture-based activities, such as daily program, weekly program and annual program involving the teachers, students, parents and government, (3) values applied such as the value of religiosity, value of nationalism, value of independence, value of integrity and value of mutual cooperation, and (4) habitation of school community by doing murojaah the memorization (repeating the memorization), fasting on Tuesday and Thursday, liqa (mentoring), pray for Dhuha, pray for Dzuhur, etc.
\end{abstract}

Keywords: Leadership, Religious Culture (1) Licensees may copy, distribute, display and perform the work and make derivative works and remixes based on it only if they give the author or derivative works and remixes based on it only for non-commercial purposes.

\section{PENDAHULUAN}

Pendidikan bertujuan untuk meningkatkan kualitas sumber daya manusia, dalam usaha meningkatkan kualitas sumber daya pendidikan, tenaga pendidik merupakan komponen sumber daya manusia yang harus dibina dan dikembangkan terus menerus untuk memperbaiki kualitas pendidikan. Pendidikan Nasional (UU Sisdiknas) Nomor 20 tahun 2003, pendidikan adalah usaha sadar dan terencana untuk mewujudkan suasana belajar dan proses pembelajaran agar peserta didik secara aktif mengembangkan nilai potensi dirinya untuk memiliki kekuatan spiritual, pengendalian diri, kepribadian, kecerdasan, akhlak mulia, serta keterampilan yang diperlukan dirinya, masyarakat, bangsa dan negara (Presiden Republik Indonesia, 2003).

Sekolah merupakan tempat belangsungnya kegiatan belajar mengajar, bukan hanya transfer pengetahuan akan tetapi bagaimana membiasakan seluruh warga sekolah disiplin dan patuh terhadap peraturan 
yang berlaku di sekolah (Rifa, 2017). Menurut Permendikbud Nomor 20 Tahun 2018 Pasal 2 ayat 2 dinyatakan nilai utama yang saling berkaitan dalam pendidikan penguatan karakter yaitu religiusitas, nasionalisme, gotong royong, kemandirian, dan integritas.

Dalam rangka meningkatkan budaya religius, kepemimpinan Kepala Sekolah sangatlah penting perannya dalam memajukan sekolah dan terlaksananya ketaatan terhadap budaya sekolah (Hadiyanto, 2004). Berdasarkan observasi awal yang dilakukan, di MI Terpadu Al-Ishlah Gorontalo sebelum 15 menit masuk kelas setiap hari Guru dibekali dengan Tilawah dan dibagi beberapa kelompok untuk murajaah (hafalan surat sesuai dengan tajwid) dan Halaqoh Qur'an Guru agenda rutin setiap pagi, pada saat sebelum jam pelajaran pertama akan dimulai siswa berbaris di luar kelasnya masing-masing, satu atau dua orang menjadi pemimpin dan mengarahkan temantemannya untuk berdoa dimulai dari membaca surat Al-fatihah, ikrar/janji Siswa MIT AlIshlah, membaca doa diberikan kemudahan, doa masuk kelas dan diwajibkan untuk seluruh kelas 1 sampai dengan 6, setelah itu guru menanyakan kepada siswa yang melaksanakan sholat 5 waktu, membuat tugas, bersalaman kepada kedua orang tua, membaca doa keluar rumah, doa naik kendaraan dan lain-lain, yang telah melaksanakan semua yang dikatakan oleh guru bisa masuk ke dalam kelas dan yang tidak melaksanakan akan diberi punishment dengan menyebutkan istighfar sesuai tingkat kesalahan yang dilakukan, Guru pun ketika terlambat 1x akan diberi peringatan, ketika terlambat $2 \mathrm{x}$ dan seterusnya maka akan diberikan punishment dengan menghafal beberapa ayat dalam AlQur'an Juz 30. Bukan hanya siswa, guru dan semua staf yang ada di MIT Al-Ishlah Gorontalo saja akan tetapi satpam, sampai cleaning service juga diberdayakan dengan menstorkan hafalan setiap hari pada saat pulang sekolah guru ada pertemuan dengan murrobi untuk melaksanakan liqa sesuai dengan jadwal yang telah disepakati.

Mencermati realita tersebut, maka demikian dipandang perlu untuk dikaji secara seksama mengenai budaya religius di MI Terpadu Al-Ishlah Gorontalo, dengan fokus penelitian adalah Kepemimpinan Berbasis Budaya Religius di MI Terpadu Al-Ishlah
Gorontalo yang dirinci menjadi sub fokus sebagai berikut: 1) Penyusunan program berbasis budaya religius di MI Terpadu AlIshlah Gorontalo, 2) Pelaksanaan kegiatan berbasis budaya religius di MI Terpadu AlIshlah Gorontalo, 3) Nilai-nilai yang diterapkan dalam kepemimpinan berbasis budaya religius di MI Terpadu Al-Ishlah Gorontalo, 4) Habituasi warga sekolah di MI Terpadu Al-Ishlah Gorontalo

Kepala sekolah sebagai pimpinan di sekolah memiliki tugas dan fungsi serta peranan yang sangat penting dalam meningkatan mutu sekolah (Yusuf, 2017). Kepemimpinan merupakan proses yang harus ada dan perlu diadakan dalam kehidupan manusia sebagai makhluk sosial. Jaya (2017) kepemimpinan diartikan sebagai kegiatan untuk memengaruhi orang-orang yang diarahkan terhadap tercapainya tujuan organisasi. Amirullah (2004) mendefinisikan kepemimpinan sebagai hubungan di mana seseorang (pemimpin) memengaruhi orang lain untuk mau bekerjasama melaksanakan tugas-tugas yang saling berkaitan guna mencapai tujuan yang diinginkan pemimpin dan kelompok (Sarboini, Surya, \& Safiansyah, 2017). Oleh sebab itu kepemimpinan yang baik adalah kepemimpinan yang mengintegrasikan orientasi tugas dengan orientasi antar hubungan manusia. Dengan mengintegrasikan dan meningkatkan keduanya kepemimpinan akan menjadi efektif, yaitu mampu mencapai tujuan organisasi tepat pada waktunya.

Pendidikan merupakan sarana strategis dalam pembentukan karakter (Maunah, 2014). Winton dalam Muchlas (2012) menjelaskan secara sederhana pendidikan karakter adalah hal positif apa saja yang dilakukan guru dan berpengaruh kepada karakter siswa yang diajarnya. Senada dengan pendapat di atas, Muslich (2011) menegaskan bahwa untuk dapat memahami pendidikan karakter itu sendiri, perlu memahami struktur antropologis manusia. Stuktur antropologis manusia terdiri atas jasad, ruh serta akal, sehingga pendidikan karakter menurut Muslich (2011) harus mencakup semua struktur antropologis manusia, atau dengan kata lain pendidikan karakter harus mencakup pada komponen kognitif, afektif, dan psikomotorik secara 
seimbang. Tujuan pendidikan karakter adalah untuk meningkatkan mutu penyelenggaraan dan hasil pendidikan yang mengarah pada pencapaian pembentukan karakter dan akhlak mulia peserta didik secara utuh, terpadu, dan seimbang (Muslich, 2011). Seperti disampaikan di atas bahwa pendidikan adalah proses internalisasi budaya ke dalam diri seseorang dan masyarakat sehingga membuat orang dan masyarakat jadi beradab. Tylor dalam Budiningsih (2004) mengartikan budaya merupakan suatu kesatuan yang unik dan bukan jumlah dari bagian-bagian suatu kemampuan kreasi manusia yang immaterial, berbentuk kemampuan psikologis seperti ilmu pengetahuan, teknologi, kepercayaan, keyakinan, seni dan sebagainya. Menurut Scheein dalam Ifliya \& Hidayah (2018) budaya adalah pola asumsi dasar yang diciptakan, ditemukan, atau dikembangkan oleh kelompok tertentu sebagai pembelajaran untuk mengatasi masalah adaptasi eksternal dan integrasi internal yang resmi dan terlaksana dengan baik. Oleh karena itu budaya diajarkan/ diwariskan kepada anggotaanggota baru sebagai cara yang dapat memahami, memikirkan, dan merasakan terkait dengan masalah-masalah tersebut.

\section{METODE}

Pendekatan yang digunakan adalah melalui pendekatan kualitatif dengan jenis penelitian studi kasus, dilakukan karena penulis berfokus untuk mengidentifikasi secara langsung mengenai Kepemimpinan Berbasis Budaya Religius di MI Terpadu AlIshlah Gorontalo. Kehadiran peneliti di lapangan sangat penting dan diperlukan secara optimal, sebagai instrumen kunci untuk mengamati, mewawancarai, dan mengobservasi, sumber data: 1) kepala madrasah, 2) direktur, 3) guru, 4) siswa, 5) cleaning service 6) orang tua siswa 7) satpam. Langkah-langkah pengumpulan data, dilakukan sebagai berikut: 1) observasi langsung, wawancara, dan 3) dokumentasi. Analisis data dilakukan melalui model interaktif Miles \& Huberman, (1994): 1) pengumpulan data, 2) reduksi data, 3) penyajian data, 4) penarikan kesimpulan. Untuk keabsahan data yang dapat dipertanggungjawabkan dilakukan dengan langkah-langkah berikut: 1) memperpanjang kehadiran peneliti di lokasi penelitian, 2) observasi yang mendalam, 3) triangulasi sumber dan triangulasi metode/teknik, 4) memberi chek. Tahap-tahap penelitian: 1) tahap persiapan lapangan, 2) tahap pelaksanaan penelitian, 3) tahap laporan.

\section{HASIL DAN PEMBAHASAN}

Berdasarkan hasil pengamatan dan wawancara secara langsung yang dilakukan dengan informan baik kepala madrasah, direktur, guru, siswa, orang tua, satpam, Cleaning Service di MI Terpadu Al-Ishlah Gorontalo didapatkan gambaran mengenai kepemimpinan berbasis budaya religius. Adapun hasil wawancara terkait dengan temuan terhadap kepemimpinan berbasis budaya religius di MI Terpadu Al-Ishlah Gorontalo dapat diuraikan sebagai berikut:

\section{Penyusunan Program Berbasis Budaya Religius di MI Terpadu Al-Ishlah Gorontalo}

Mengenai penyusunan program kepemimpinan berbasis budaya religius terhadap perencanaan di MI Terpadu Al-Ishlah Gorontalo, kepala sekolah melakukan rapat kerja guru di tiap semester dengan melibatkan seluruh personel sekolah. Peran kepala sekolah dalam penyusunan program sekolah berbasis budaya religius di MI Terpadu Al-Ishlah Gorontalo sudah baik dan sudah sesuai dengan visi, misi sekolah. Program sekolah berbasis budaya religius, peran kepala sekolah adalah melakukan perencanaan pada saat rapat kerja awal semester dengan melibatkan semua guru dan yang ada di MIT dilaksanakan perkajusami, kepala sekolah memberikan tugas kepada guru-guru per jenjang untuk merencanakan program atau kegiatan apa yang akan dilakukan pada 1 semester diberlakukan juga pada wakil kepala sekolah bagian kurikulum, bagian kesiswaan, dan juga bagian sarana prasarana.

Pada saat membuat program, sudah harus ada perincian anggaran agar diketahui anggaran yang dikeluarkan dan diperlihatkan ke kepala sekolah jika sudah sesuai maka akan disetujui oleh kepala sekolah. Untuk memulai dan mengakhiri rapat kerja selalu diawali dan 
ditutup dengan membaca surah juz 30 yang sudah ditentukan oleh kepala sekolah 1 hari berapa ayat dan itu berlaku sampai hari terakhir. Selain membuat perencanaan program, kepala sekolah selalu mengingatkan aturan-aturan kepegawaian yang wajib diikuti oleh seluruh warga sekolah seperti disiplin berpakaian, mengucapakan salam dan lain sebagainya. Selain itu, pada saat rapat kerja akan dievaluasi kinerja guru selama 1 semester mengajar dalam kelas. Berikut diagram konteks program budaya religius di MI Terpadu Al-Ishlah Gorontalo:

Gambar 1.

Diagram Konteks Penyusunan Program Budaya di MI Terpadu AlIshlah Gorontalo

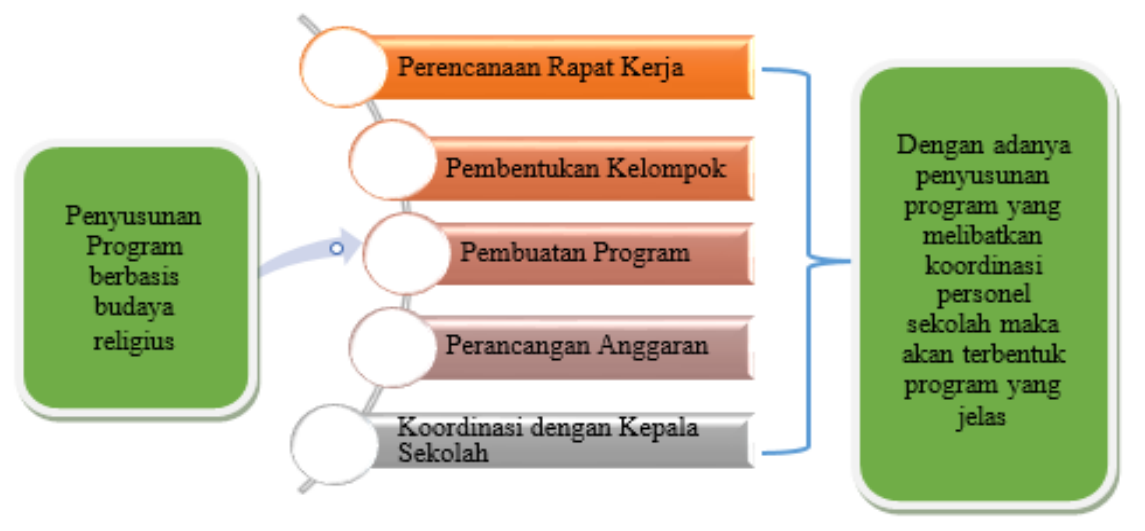

Didukung oleh pendapat Mulyasa (2004) menjelaskan bahwa kepala sekolah adalah motor penggerak dan penentu kebijakan madrasah, yang akan menentukan bagaimana tujuan-tujuan dalam pendidikan pada umumnya dapat direalisasikan. Hal ini sejalan dengan Djati dalam Hardono, Haryono, \& Yusuf (2017) yang mengemukakan bahwa kepala sekolah salah satunya berfungsi sebagai administrator, yang bertugas untuk menyusun program yang mencakup pengajaran, kesiswaan, kepegawaian, keuangan, dan penyediaan fasilitas-fasilitas yang diperlukan. Perencanaan ini selanjutnya dituangkan dalam rencana tahunan sekolah yang dijabarkan dalam dua program semester. Program pengajaran, program kesiswaan, kepegawaian, keuangan sarana dan prasarana (Azmi, 2015).

\section{Pelaksanaan Kegiatan Berbasis Budaya Religius di MI Terpadu Al-Ishlah Gorontalo}

Pelaksanaan kegiatan berbasis budaya religius di MI Terpadu Al-Ishlah Gorontalo melaksanakan pendidikan keagamaan dalam kehidupan sehari-hari sehingga menjadi suatu budaya religius di sekolah. Melalui programnya tersebut, MI Terpadu Al-Ishlah Gorontalo berupaya untuk menghasilkan peserta didik yang mempunyai landasan agama yang kuat dan berkarakter religius. Budaya religius sekolah diyakini merupakan salah satu aspek yang berpengaruh terhadap perkembangan karakter anak. Hal ini sejalan dengan pendapat Kurnia \& Qomaruzzaman (2012) yang menyatakan bahwa budaya sekolah adalah kultur akademis, inti dari kultur akademis mengatur para pendidik agar mereka memahami cara bersikap, terhadap profesinya, beradaptasi terhadap rekan kerja dan lingkungan kerjanya, serta berlaku reaktif terhadap kebijakan pimpinannya sehingga terbentuklah sebuah sistem nilai, kebiasaan, citra akademis, dan etos kerja.

Kepala sekolah melakukan kegiatankegiatan yang bisa meningkatkan pemahaman kepada seluruh warga sekolah dengan adanya kegiatan yang bernuansa islami, sehingga warga sekolah diharapkan mampu untuk membentuk akhlak mulia sesuai ajaran Islam dengan mengikuti kegiatan-kegiatan yang dilakukan oleh sekolah. Hasil temuan didapatkan bahwa program manasik haji dilaksanakan 1 tahun 1 kali melibatkan semua unit. Memberikan perhatian dan motivasi kepada siswa dengan diadakannya kegiatan tersebut menambah pemahaman, pengetahuan kepada Siswa tentang pelaksanaan haji mulai dari persiapan sampai berkeliling $k a^{\prime} b a h$. 
Gurupun ada kegiatan-kegiatan yang berkaitan dengan peningkatan budaya religius. Kepala Sekolah MI Terpadu Al-Ishlah Gorontalo memberikan suatu perhatian untuk seluruh warga sekolah agar lebih meningkatkan karakter dengan diadakannya program sekolah berbasis budaya religius di MI Terpadu AlIshlah maka penanaman nilai-nilai akan terbentuk dan tercapainya tujuan pendidikan. Selain itu, dapat memudahkan siswa untuk lebih mengembangkan potensi yang mereka miliki dan memberi perubahan serta dapat meningkatkan mutu pendidikan, dapat membantu siswa dalam pencapaian pendidikan yang baik. Pada tahap pelaksanaan ini, berdampak juga pada prestasi siswa di MI Terpadu Al-Ishlah Gorontalo, karena telah mampu menjalankan program tersebut dengan baik. Sudah banyak siswa yang berprestasi dan mampu bersaing dengan sekolah-sekolah lain baik tingkat kota, provinsi dan nasional.

Pelaksanaan yang berarti usaha atau tindakan yang dilakukan untuk mencapai tujuan organisasi atau dapat diartikan apa yang telah direncanakan dan diorganisasikan untuk mencapai tujuan organisasi sudah mulai dilaksanakan atau dijalankan. Didukung oleh pendapat Kurnia \& Qomaruzzaman (2012) konsep budaya sekolah pada dasarnya dapat digunakan untuk melihat ke arah mana bergulirnya perubahan baik positif maupun negatif yang terjadi dalam konteks mikro (sekolah) sekaligus menjadi modal untuk melakukan evaluasi secara terus menerus untuk peningkatan kualitas. Bahwasanya budaya yang ada di sekolah dapat digunakan sebagai tolak ukur keberhasilan sekolah dalam mencapai prestasi sekolah dan dibawa ke arah mana sekolah tersebut.

Hal ini sejalan dengan teori yang ditulis oleh teori yang ditulis Saleh (2000), terdapat macam-macam kegiatan spiritual untuk pembinaan dan ketakwaan terhadap Tuhan Yang Maha Esa dapat dibagi kedalam empat bagian yaitu 1) kegiatan rutin terdapat sholat Zuhur berjamaah, berdoa awal dan di akhir pembelajaran, membaca ayat Al-qur'an secara bertadarus sebelum masuk jam pelajaran, sholat dhuha pada waktu istirahat, 2) kegiatan mingguan terdapat infaq shadaqah setiap hari Jum'at, mentoring yaitu bimbingan senior kepada siswa junior dengan materi yang bernuansa Islami, setiap hari Jum'at siswa memakai busana muslimah, 3) kegiatan bulanan yaitu khusus bulan Ramadhan kegiatan yang dilaksanakan yaitu buka puasa bersama, shalat tarwih di masjid sekolah, tadarus, ceramah Ramadhan, 4) kegiatan tahunan yaitu peringatan Isra' Mi'raj, peringatan maulid nabi S.A.W, peringatan nuzulul qur'an.

Fungsi pendidikan agama di sekolah salah satunya fungsi penyesuaian yakni membimbing anak didik untuk menyesuaikan diri dengan lingkungan baik lingkungan fisik maupun sosialnya dapat mengarahkan untuk dapat mengubah lingkungan sesuai dengan ajaran Islam (Ali, 2015). Guru harus menciptakan suasana yang kondusif dan terjadi interaksi yang baik antara guru dan siswa. Menurut Masaong \& Ansar (2011) bahwa proses belajar mengajar adalah suatu proses interaksi antara guru dan peserta didik yang berisi berbagai kegiatan yang bertujuan agar terjadi proses belajar (perubahan tingkah laku) pada diri peserta didik. Dapat dipahami bahwa kesuksesan hidup seseorang tidak hanya ditentukan oleh kecerdasan melalui akal saja, tetapi ketiga kecerdasan IQ, EQ, SQ harus berjalan dengan selaras (Amirullah, 2004).

\section{Pihak-pihak Terlibat}

Untuk pihak-pihak yang terlibat secara umum seluruh warga sekolah terlibat dalam program ini namun kita sudah membagi ada beberapa penanggung jawab khusus untuk religius kita ada tim ibadah, tim ibadah itu dia di bawah Waka Kesiswaan jadi ada tim ibadah dan itu bertanggung jawab atas seluruh kegiatan yang religiusnya siswa termasuk jalasahruhiyah siswa, buka puasa bersama, evaluasi puasa senin kamisnya siswa, evaluasi sholatdhuhanya siswa, juga dengan evaluasi amalan yaumiyah guru, amalan-amalan harian guru, jadi dievaluasi setiap hari oleh tim ibadah tetap berkordinasi dengan Wakil Kepala Madrasah bagian Kesiswaan. Orang tua sangat dibutuhkan, utamanya pendampingan anak dari perilakunya di rumah harus ada pendampingan orang tua, evaluasi sholatnya, memurajaah hafalannya dan beberapa perilaku-perilaku baiklah yang temasuk makan dan minum sambil duduk, keluar rumah menggunakan pakaian yang tertutup atau menutup aurat 
untuk akhwat, ini sering kita ingatkan ke orang tua utamanya kalau ada yang libur 3 hari seperti Jum'at, Sabtu, Ahad. Selain itu, melibatkan juga stakeholder seperti walikota, kementerian agama dalam kegiatan-kegiatan yang dilaksanakan oleh sekolah. Seperti yang dikemukakan oleh Zakiah (1984) bahwa pada umumnya pendidikan dalam rumah tangga bukan berpangkal tolak dari kesadaran dan pengertian yang lahir dari pengetahuan mendidik, melainkan secara kodrati suasana dan strukturnya memberikan kemungkinan alami membangun situasi pendidikan. Hal ini didukung oleh pendapat Masaong \& Ansar (2011) yang menyatakan bahwa peran orang tua sebagai partner dan pendukung. Mereka dapat berpartisipasi dalam proses sekolah, mendidik peserta didik secara kooperatif, berusaha membantu perkembangan yang sehat kepada sekolah dengan memberi sumbangan sumber daya informasi, mendukung sekolah pada saat mengalami kesulitan dan krisis. Pendapat Kurniawan (2013) sebagai unit sosial terkecil dalam masyarakat, keluarga merupakan lingkungan pendidikan pertama dan utama dalam menanamkan norma dan mengembangkan kebiasaaan dan perilaku yang dianggap penting bagi kehidupan pribadi, keluarga dan masyarakat. Hal ini sejalan dengan yang dikemukakan oleh Wiliandani, Wiyono, \& Sobri (2016) yang menyatakan bahwa masing-masing komponen sekolah guru, siswa orang tua/wali, dan juga masyarakat memainkan peran yang penting bagi terwujudnya budaya sekolah. Mereka harus mencurahkan dan memberikan perhatiannya terhadap bentuk nilai, moral, dan kebiasaan-kebiasaan terpuji di lingkungan sekolah. Berikut diagram konteks pelaksanaan kegiatan berbasis budaya religius di MI Terpadu Al-Ishlah Gorontalo:

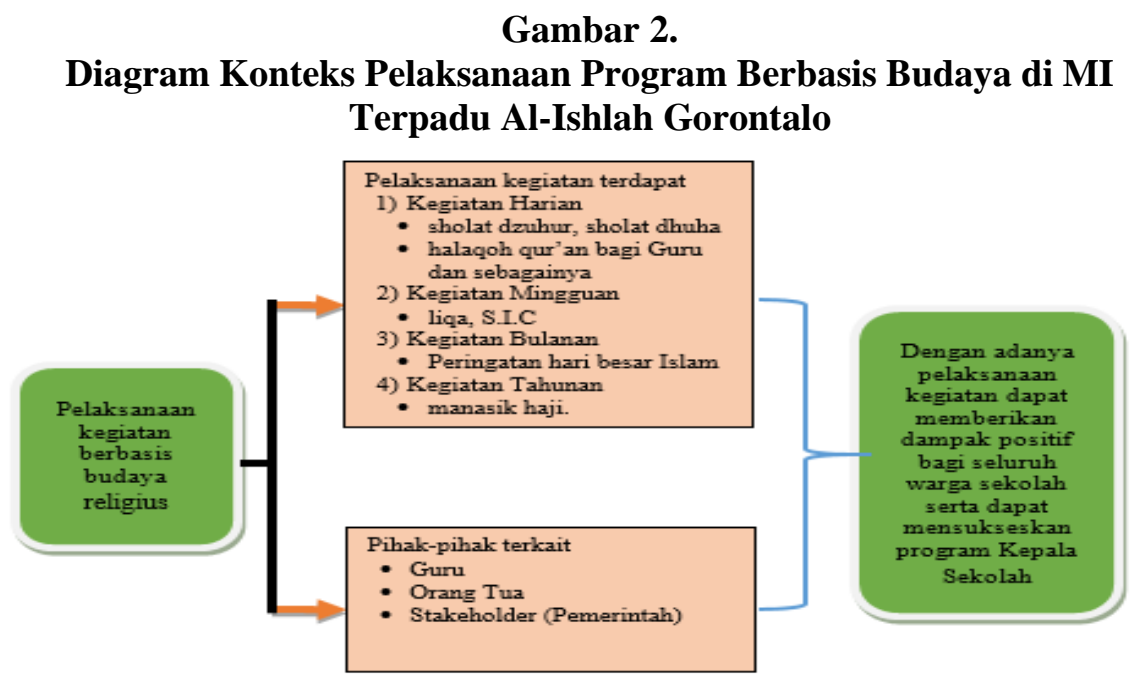

Nilai-nilai yang ditanamkan di lingkungan MI Terpadu Al-Ishlah Gorontalo antara lain: a) nilai spiritual, b) nilai kedisiplinan, 3) nilai amanah. Menurut Steeman dalam Muhaimin (2009) nilai adalah sesuatu yang dijunjung tinggi, yang mewarnai dan menjiwai tindakan seseorang.Nilai menjadi pengarah, pengendali, penentu perilaku seseorang. Untuk menciptakan sekolah berbasis budaya religius maka MI Terpadu Al Ishlah Gorontalo menerapkan nilai-nilai budaya religius yaitu terdiri dari: a) nilai agama, b) nilai kedisiplinan, c) nilai kerja dan tanggung jawab. Muhaimin (2009) memberikan contoh standar dan tahapan yang berkelanjutan dalam pengembangan budaya religius seperti misalnya: a) dilaksanakan sholat berjamaah dengan tertib dan disiplin di masjid madrasah, b) tidak terlibat dalam perkelahian antar peserta didik, c) sopan santun berbicara antara peserta didik, peserta didik dengan guru dan tenaga kependidikan, antara guru dengan guru, antara guru dan tenaga kependidikan lainnya, d) cara berpakaian peserta didik dan Guru yang islami, e) cara pergaulan peserta didik dan guru sesuai norma Islam, terciptanya budaya senyum, salam dan sapa dan lain sebagainya. Dengan adanya standar dan tahapan tersebut, 
sangat penting untuk proses penanam nilainilai agama pada warga sekolah.

\section{Nilai Religiusitas}

Berdasarkan deskripsi hasil penelitian bahwa, nilai karakter religius yang mencerminkan keberimanan terhadap Tuhan yang Maha Esa yang diwujudkan dalam perilaku melaksanakan ajaran agama dan kepercayaan yang dianutnya. Nilai religiusitas perlu ditanamkan agar membentuk budaya religius yang mantap di lembaga pendidikan tersebut.

Berdasarkan hasil temuan di MI Terpadu Al-Ishlah Gorontalo, kepala sekolah dan guru melaksanakan kegiatan yang berhubungan dengan nilai-nilai yang dapat membentuk karakter warga sekolah di lingkungan sekolah agar terbentuk budaya yang bersifat religius. Nilai karakter religius ini meliputi tiga dimensi relasi sekaligus, 1) hubungan individu dengan Tuhan yaitu dengan melaksanakan sholat Dhuha, sholat Dzuhur, karena sholat dianggap sebagai tiang agama. Melaksanakan sholat merupakan cara untuk memperkuat iman dan bukti kecintaan kita terhadap agama yang diyakini, melaksanakan puasa sunnah senin kamis untuk melaksanakan ibadah agama Islam dan menyempurnakan keimanan, selain itu membaca doa-doa, 2) Individu dengan sesama yaitu memakai barang teman meminta izin, meminta maaf ketika berselisih, tidak bersentuhan atau bersalaman sesama ikhwan dan akhwat, makan tidak boleh berjalan (adap makan), menghormati yang lebih tua dan mampu bersikap sopan dengan memberikan salam saat bertemu, 3) Individu dengan alam semesta (lingkungan) yaitu menjaga lingkungan sekitar dengan cara tidak membuang sampah sembarangan karena sudah disediakan tempat sampah di masingmasing kelas, serta terdapat program sekolah yang harus diikuti seluruh warga sekolah tidak boleh memakai sepatu dalam ruangan karena sudah disediakan tempat sepatu, 4) Toleransi yaitu guru memberikan pelayanan yang sama kepada seluruh siswa tanpa membedakan salah satunya dengan adanya pelatihan Metode Al-Wafa serta siswa bekerja dalam kelompok yang berbeda, menghormati yang lebih tua, dan menghargai pendapat orang lain
(Warasto, 2018). Di samping itu untuk sekolah-sekolah yang mempunyai basis keagamaan ada 17 nilai yang dapat membentuk karater peserta didik di sekolah, 5 di antaranya adalah nilai keteladanan (Uswatun Hasanah), kepatuhan (tho'ah), kemandirian (I'timadu alan nafs), kesalehan (Sholeh) dan kedisiplinan (Intidhom).

\section{Konteks Nilai-nilai yang Diterapkan dalam Kepemimpinan Berbasis Budaya}

\section{Nilai Nasionalisme}

Berdasarkan hasil penelitian dapat dijelaskan bahwa nasionalis merupakan sumber yang membangun nilai karakter siswa, adapun temuan penelitian tentang nilai nasionalis di MI Terpadu Al-Ishlah Gorontalo yaitu; 1) cinta tanah air dengan memajang foto Presiden dan Wakil Presiden, memajang foto pahlawan, serta pembacaan ikrar/janji yang diselipkan dengan hafalan Al-Qur'an, 2) menghargai prestasi yaitu memberikan reward kepada siswa yang berprestasi dengan adanya papan bintang kelas untuk memotivasi siswa agar disiplin dan giat belajar, 3) demokratis yang dilihat yaitu dari kepala sekolah mengambil keputusan dengan melibatkan seluruh personel sekolah yaitu guru dan karyawan.

\section{Nilai Kemandirian}

Berdasarkan hasil penelitian yang termasuk dalam nilai kemandirian di MI Terpadu Al-Ishlah Gorontalo yaitu; 1) disiplin yang ditandai dengan disiplin waktu datang ke sekolah, disiplin masuk dalam kelas, disiplin tidak memakai sepatu dalam kelas, disiplin waktu istirahat, disiplin mengambil air wudhu, disiplin waktu pulang, melaksanakan sholat tepat waktu, disiplin dalam hal hafalan doadoa, disiplin berpakaian, membiasakan menaati peraturan kelas, membiasakan mengumpulkan tugas tepat waktumaka secara otomatis tertanam nilai-nilai kedisiplinan dalam diri seseorang tersebut. Dengan adanya kedisiplinan dapat membuat seseorang menjadi lebih tertib dan teratur dalam menjalankan aktifitas serta dapat mengerti bahwa kedisiplinan sangat penting bagi masa depannya kelak agar dapat menjadi panutan setiap orang, karena dapat membangun kepribadian seseorang yang kokoh dan bisa 
diharapkan bagi semua, 2) berani yaitu siswa memberanikan diri untuk dievaluasi oleh guru terkait hafalan-hafalan yang telah dihafal 1 semester, 3) rasa ingin tahu siswa bertanya kepada guru ketika materi yang kurang dimengerti.

\section{Nilai Integritas}

Berdasarkan hasil temuan di MI Terpadu Al-Ishlah Gorontalo 1) kejujuran yaitu tidak mencontek ketika ulangan, 2) keteladanan ditandai dengan kepala sekolah berperilaku yang terpuji, memberi teladan melalui tindakan sehari-hari dengan menunjukkan kepada para bawahan mengenai apa yang harus mereka lakukan, kepala sekolah melalui teladan dengan adanya disiplin waktu, kepatuhan terhadap aturan dan sebagainya karena seorang pemimpin harus menjadi contoh dan menjadi panutan bagi bawahannya, 3) tanggung jawab (amanah), kepala sekolah tidak hanya bertanggung jawab terhadap masalah akademik, tetapi juga meliputi non akademik. Nilai-nilai yang diterapkan meningkatkan kepemimpinan berbasis budaya religius melalui nilai tanggung jawab yaitu kepala sekolah menjalankan perannya sebagai pemimpin dengan baik.

Gambar 3.

Diagram Konteks Nilai-nilai yang Diterapkan dalam Kepemimpinan Berbasis Budaya di MI Terpadu Al-Ishlah Gorontalo

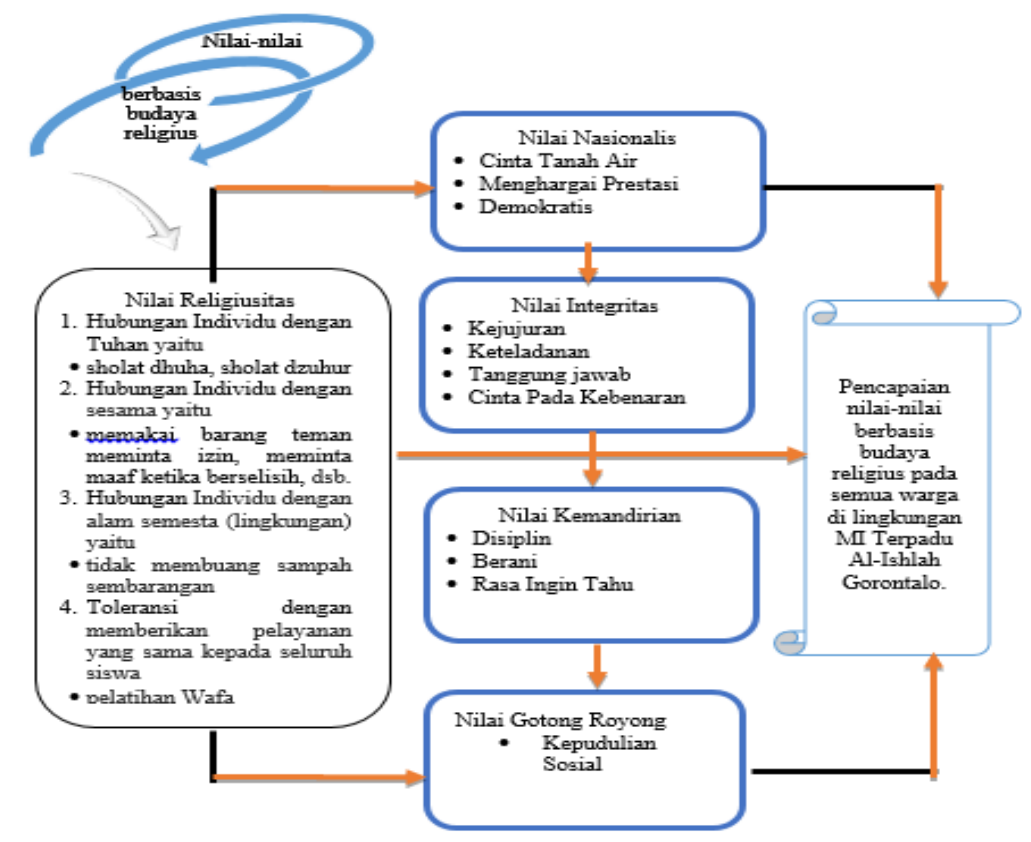

Berdasarkan hasil temuan tersebut adanya pembimbingan/pembinaan guru, memberikan informasi kepada orang tua melalui undangan untuk rapat, memperhatikan disiplin dengan cara mengawasi guru dan siswa pada saat proses belajar mengajar. Kepala sekolah juga mempunyai tanggung jawab untuk mengajar didalam kelas dan kepala sekolah menggantikan guru yang tidak sempat hadir memberikan materi pembelajaran, 4) cinta pada kebenaran yaitu ketika terjadi perselisihan dengan teman langsung secara spontan meminta maaf.

\section{Nilai Gotong Royong}

Berdasarkan deskripsi hasil penelitian yang termasuk dalam nilai gotong royong yang ada di MI Terpadu Al-Ishlah Gorontalo yaitu 1) kepedulian Sosial yaitu memberikan donasi peduli Palestina dan Rohingya yang terkumpul sebanyak Rp 16.604.500,- selain itu MIT juga bekerjasama dengan orang tua dan masyarakat untuk memberikan sumbangan berupa jilbab dan sembako kepada orang-orang yang 
membutuhkan. Maka dapat disusun diagram konteks nilai-nilai budaya sekolah berbasis kecerdasan spiritual yang di tanamkan di SMP Negeri 2 Telaga.

Budaya religius di MI Terpadu AlIshlah Gorontalo merupakan kegiatan yang sudah menjadi kebiasaan yang mengandung nilai-nilai religius. Wujud budaya religius yang ada di MI Terpadu Al-Ishlah Gorontalo adalah bentuk dari kegiatan spiritual dan kebiasaan dalam perilaku sehari-hari. Kegiatan keagamaan tersebut ada yang dilaksanakan setiap minggu dan tahunan dan bahkan ada yang dilaksanakan setiap hari. Penerapan pembiasaan religius di sekolah tersebut dibiasakan sholat 5 waktu, menambah hafalan, terdapat puasa senin kamis kemudian Sholatlail, Sholat Dhuha, pembacaan Asmaul Husna setiap dua pekan pada saat Senin, shalat berjamaah, makan dengan tangan kanan, makan sesuai dengan ajaran Rasulullah dan minum tidak boleh berjalan, tutur berbicara, selalu mengucapkan terima kasih dan membiasakan mengembalikan sesuatu menggunakan tangan kanan, mampu membuat Siswa lebih siap menerima pelajaran. Pada saat masuk di depan gerbang untuk kelas 4, 5, 6 sudah diberlakukan aturan untuk perempuan yang bersalaman dengan guru laki-laki tidak menyentuh. Begitu juga untuk laki-laki tidak bisa bersentuhan dengan guru perempuan. Pembiasaan yang dilakukan dengan adanya kegiatan rutin. Kegiatan rutin merupakan kegiatan yang dilakukan setiap saat bagi warga sekolah secara terus menerus. Maka dapat disusun diagram konteks tentang habituasi warga sekolah dalam penerapan budaya religius di MI Terpadu Al-Ishlah Gorontalo melalui kegiatan yang dijabarkan dalam gambar berikut:

\section{Gambar 4. \\ Diagram Konteks Habituasi Warga Sekolah dalam Penerapan Budaya Riligius di MI Terpadu Al-Ishlah Gorontalo}

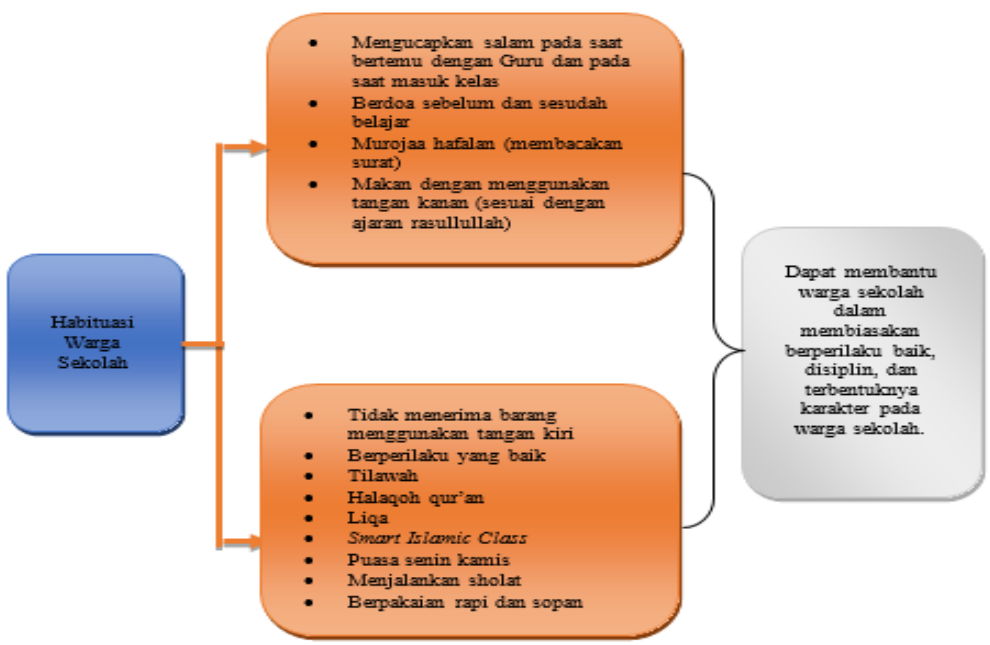

Dengan adanya pembiasaan di sekolah, semua warga yang ada di lingkungan MI Terpadu Al-Ishlah akan terbiasa juga pada saat di rumah. Menurut Baharuddin \& Zakaria (2018) mengemukakan hal yang tidak kalah pentingnya dalam kehidupan manusia (pemimpin pendidikan dan guru serta peserta didik) adalah membiasakan menerapkan kebiasaan spiritual dalam kehidupan sehari- hari. Kebiasaan ini sebaiknya dijadikan praktik rutin yang secara otomatis menghubungkan manusia dengan Allah. Seperti dikatakan oleh Ali (2015) bahwa suasana religius di sekolah dapat menciptakan para civitas akademika sekolah termasuk para Siswa menjadi terbiasa beribadah, baca Al-Qur'an dan shalat malam, berpakain bagus-sopan. Hal ini sebagaimana diungkapkan oleh Tolchah (2015), pembiasaan 
adalah model utama dalam pengajaran agama Islam, tidak hanya dalam lingkungan keluarga dan kehidupan sehari-hari tetapi juga dilakukan dalam lingkungan sekolah sebagai saran untuk menuntut ilmu. Berdasarkan temuan dalam fokus penelitian antara lain: 1) penyusunan program berbasis budaya religius,
2) pelaksanaan kegiatan berbasis budaya religius, 3) nilai-nilai berbasis budaya religius, 4) habituasi warga sekolah. Maka dapat disusun diagram konteks secara keseluruhan tentang kepemimpinan berbasis budaya religius, yang dijabarkan dalam gambar berikut:

\section{Gambar 5. \\ Diagram Konteks Secara Keseluruhan Kepemimpinan Berbasis Budaya Riligius di MI Terpadu Al-Ishlah Gorontalo}

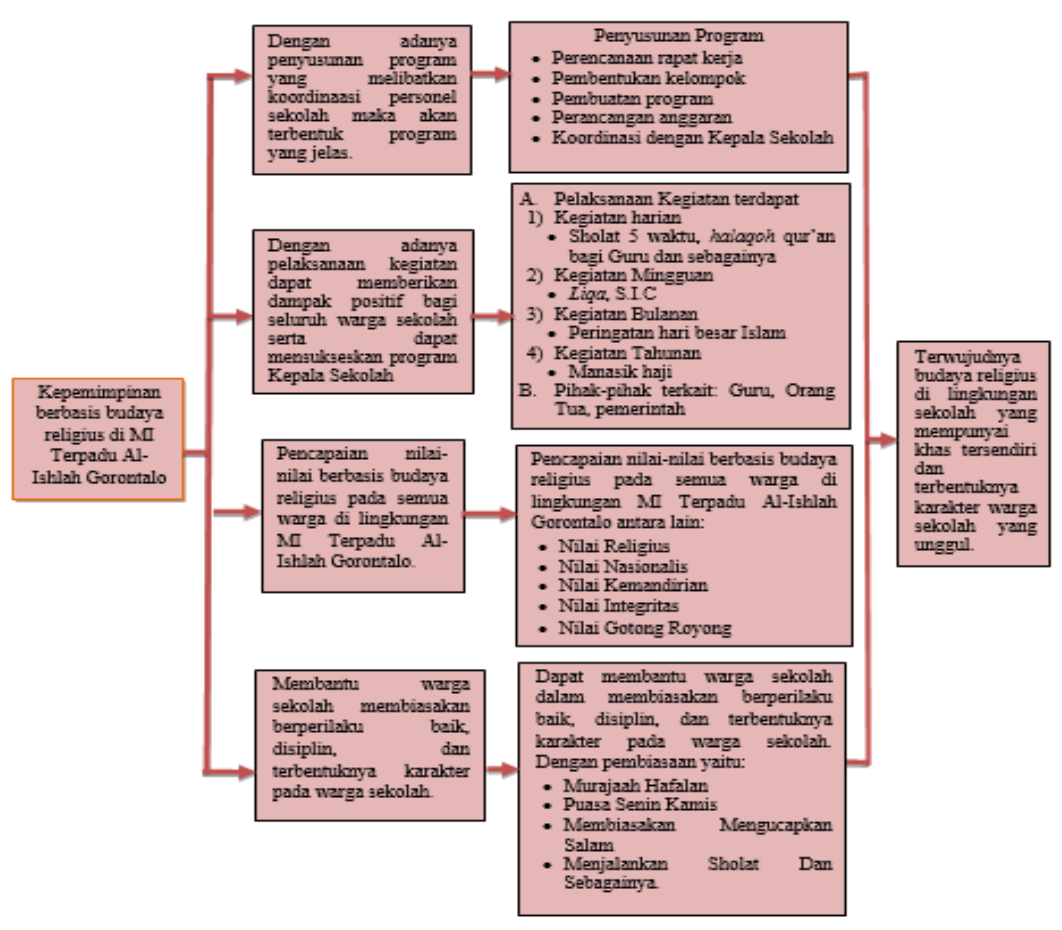

\section{SIMPULAN DAN SARAN}

Simpulan yang dapat ditarik dari penelitian ini, antara lain; 1) penyusunan program sekolah berbasis budaya religius di MI Terpadu Al-Ishlah Gorontalo, yaitu melakukan perencanaan rapat kerja, pembentukan kelompok, pembuatan program, perancangan anggaran, dan koordinasi dengan kepala sekolah, 2) pelaksanaan kegiatan berbasis budaya religius di MI Terpadu AlIshlah Gorontalo, antara lain a) pelaksanaan program kegiatan berbasis budaya religius sudah berjalan dengan baik dengan adanya kegiatan sekolah yaitu kegiatan harian, kegiatan mingguan, kegiatan bulanan, kegiatan tahunan, b) pihak-pihak terkait dengan melibatkan guru, orang tua, dan pemerintah, 3) nilai-nilai yang diterapkan dalam kepemimpinan berbasis budaya religius di MI Terpadu Al-Ishlah Gorontalo yaitu a) nilai religiusitas, b) nilai nasionalisme, c) nilai kemandirian, d) nilai integritas, e) nilai gotongroyong, 4) habituasi warga sekolah dalam penerapan budaya religius di MI Terpadu AlIshlah Gorontalo, dalam hal ini kepala sekolah melakukan suatu pembiasaan pada warga sekolah dalam peningkatan budaya religius seperti murajaah hafalan, puasa senin-kamis dan sebagainya

Sedangkan saran-saran yang akan disampaikan, antara lain: 1) diharapkan bagi kepala sekolah agar lebih meningkatkan lagi budaya religius serta prestasi-prestasi yang ada di MI Terpadu Al-Ishlah Gorontalo dan menjalankan selalu program tersebut agar memudahkan warga sekolah dalam mengembangkan pemahaman mengenai agama 
Islam, 2) diharapkan bagi guru dapat memanfaatkan sebagai perbaikan untuk proses belajar mengajar di kelas serta membantu siswa dalam memiliki kemampuan yang lebih unggul, 3) diharapkan bagi siswa agar tetap dapat melakukan pembiasaan dalam meningkatkan budaya religius, 4) diharapkan bagi peneliti lain bisa menjadi referensi atau bahan pertimbangan

\section{DAFTAR PUSTAKA}

Ali, N. (2015). Penciptaan Suasana Religius di Sekolah. Malang: Maliki Press.

Amirullah. (2004). Pengantar Manajemen. Yogyakarta: Graha Ilmu.

Azmi, N. (2015). Potensi Emosi Remaja dan Pengembangannya. SOSIAL HORIZON: Jurnal Pendidikan Sosial, 2(1), 36-46.

Baharuddin, \& Zakaria, R. (2018). Pengaruh Kecerdasan Spiritual terhadap Peningkatan Kinerja Guru di SMA Negeri 3 Takalar Kabupaten Takalar. JURNAL IDAARAH, 2(1), 1-10.

Budiningsih, A. (2004). Pembelajaran Moral Berpijak pada Karakteristik Siswa. Jakarta: Rineka Cipta.

Hadiyanto, H. (2004). Mencari Sosok Desentralisasi Manajemen Pendidikan di Indonesia. Jakarta: Rineka Cipta.

Hardono, Haryono, \& Yusuf, A. (2017). Kepemimpinan Kepala Sekolah, Supervisi Akademik, dan Motivasi Kerja dalam Meningkatkan Kinerja Guru. Educational Management, 6(1), 26-33.

Ifliya, M. G., \& Hidayah, S. N. (2018). Upaya Kepala Madrasah dalam Membina Budaya Organisasi dan Kinerja Guru dalam Pembelajaran di MIN 5 Majalengka. Manageria: Jurnal Manajemen Pendidikan Islam, 3(1), 2145.

Jaya, H. N. (2017). Keterampilan Dasar Guru untuk Menciptakan Suasana Belajar yang Menyenagkan. Didaktis: Jurnal Pendidikan Dan Ilmu Pengetahuan, 17(1), 23-35.

Kurnia, A., \& Qomaruzzaman, B. (2012).
Membangun Budaya Sekolah. Bandung: Remaja Rosdakarya.

Kurniawan, S. (2013). Pendidikan Karakter: Konsepsi \& Implementasinya Secara Terpadu di Lingkungan Keluarga, Perguruan Tinggi, \& Masyarakat. Yogyakarta: Ar-Ruzz Media.

Masaong, \& Ansar. (2011). Manajemen Berbasis Sekolah. Gorontalo: Sentra Media.

Maunah, B. (2014). Implementasi Pendidikan Karakter dalam Pembentukan Kepribadian Holistik Siswa. Jurnal Pendidikan Karakter, V(1), 90-101.

Miles, M. B., \& Huberman, M. A. (1994). Qualitative Data Analysis: An Expanded Sourcebook. Beverly Hills: SAGE Publications.

Muhaimin. (2009). Rekonstruksi Pendidikan Islam, dari Paradigma Pengembangan, Manajemen Kelembagaan, Kurikulum hingga Strategi Pembelajaran. Jakarta: Raja Grafindo Persada.

Mulyasa, E. (2004). Menjadi Kepala Sekolah Profesional. Bandung: PT Remaja Rosdakarya.

Muslich, M. (2011). Pendidikan Karakter: Menjawab Tantangan Krisis Multi Dimensional. Jakarta: PT Bumi Aksara.

Presiden Republik Indonesia. Undang-Undang Sistem Pendidikan Nasional, Pub. L. No. 20 (2003). Indonesia.

Rifa, M. A. (2017). Strategi Pengembangan Kecerdasan Moral Siswa di Sekolah Berbasis Islamic Boarding School. In Prosiding Konferensi Nasional Kewarganegaraan III (pp. 116-124). Yogyakarta.

Saleh, A. R. (2000). Pendidikan Agama dan Keagamaan, Misi, Visi, dan Aksi. Jakarta: PT Gemawinda Paca Perkasa.

Sarboini, Surya, J., \& Safiansyah, W. (2017). Pengaruh Kepemimpinan dan Team Work terhadap Kinerja Pegawai pada PT . PLN (PERSERO) Cabang Banda Aceh. Jurnal Ekonomi Dan Manajemen Teknologi, 1(2), 86-90. 
Tolchah, M. (2015). Filsafat Pendidikan Islam: Konstruksi Tipologis dalam Pengembangan Kurikulum. Jurnal TSAQAFAH, 11(2), 381-398.

Warasto, H. N. (2018). Pembentukan Akhlak Siswa. JURNAL MANDIRI: Ilmu Pengetahuan, Seni, Dan Teknologi, 2(1), 65-86.

Wiliandani, A. M., Wiyono, B. B., \& Sobri, A. Y. (2016). Implementasi Pendidikan Karakter dalam Pembelajaran di Sekolah
Dasar. Jurnal Pendidikan Humaniora, 4(3), 132-142.

Yusuf. (2017). Pengaruh Kepemimpinan Kepala Sekolah dan Pelayanan terhadap Kepuasan Siswa di SMA Negeri Kabupaten Berau. Jurnal Akuntabilitas Manajemen Pendidikan, 5(2), 240-249.

Zakiah, D. (1984). Kesehatan Mental Peranannya dalam Pendidikan dan Pengajarannya. Jakarta: Gunung Agung. 